\title{
EFFECT OF GLUTAMIC ACID AND CYSTEINE ON OXIDATIVE STRESS MARKERS IN RATS
}

\author{
N. O. SALYHA \\ Institute of Animal Biology, National Academy \\ of Agrarian Sciences of Ukraine, Lviv; \\ e-mail:ynosyt@yahoo.com
}

Received: 7 May 2020; Accepted: 13 November 2020

Epinephrine (EPI) surges is known to be associated with stress induction and raising risk of heart strokes. The search for effective, nontoxic substances with antioxidative effects has been intensified in recent years. We focused our attention on two amino acids: L-glutamic acid (Glu) and L-cysteine (Cys). Our goal was to compare the effects of Glu, Cys and Glu in combination with Cys intraperitoneal administration on the antioxidant system indicators and the content of lipid peroxidation products in myocardium and spleen tissues of rats subjected to experimental EPI-induced stress. Rats were divided into five groups: EPI, EPI/Glu, EPI/ Glu/Cys, EPI/Cys and control. The reduced glutathione (GSH) and TBA-active products level, glutathione peroxidase (GPx,), glutathione-S-transferase (GST), glutathione reductase (GR) and glucose-6-phosphate dehydrogenase (G6PDH) activity in tissues were measured. Our results indicate that epinephrine-induced stress increased the content of the lipid peroxidation products in myocardium and reduced the level of GSH in myocardium and spleen tissues of rats. Increasing of GPX activity in spleen of only stressed animals were observed, while the GPx activity in groups of rats treated with amino acids (Glu, Glu/Cys, Cys) was significantly lowered. The obtained results suggest that the GR activity was significantly inhibited by stress in all investigated groups in spleen and epinephrine-induced rats and EPI/Cys groups of rats in myocardium. In rats treated with amino acids (particularly, Glu and Glu/Cys groups), we observed no significant difference in studied parameters. Our results indicate that application of Glu, Cys alone or in combination can increase GSH content in both studied tissues and activity of some antioxidative enzymes, and thus partially mitigated of epinephrine-induced stress in rats.

Key words: L-glutamic acid, L-cysteine, oxidative stress, GSH, antioxidant enzymes.

$\mathrm{T}$ he problem of stress, in particular, oxidative stress, and its effects on various functional systems of the organism remains relevant for modern biology and medicine. Stress can be a factor that leads to organs damage and the development of diseases. Oxidative stress reflects an imbalance between the reactive oxygen species (ROS) production on one hand, and antioxidant defenses on the other [1-3]. Oxidative stress occurs in condition when excess free radicals overwhelm the capacity of antioxidant systems. Severe oxidative stress can lead to the molecular damage to lipids, proteins and DNA, cell dysfunction and ultimately cell death $[4,5]$. The system of antioxidant protection (enzymatic and non- enzymatic links of the antioxidant defense system) limits the process of free radical oxidation of lipids and proteins.

The search for effective, nontoxic substances with antioxidative effects has been intensified in recent years. We focused our attention on two amino acids: L-glutamic acid (Glu) and L-cysteine (Cys). Little is known about the antioxidant effects of these aminoacids in rats. The Glu is a central metabolic hub of the cell and as such is implicated in numerous physiological and metabolic functions in the organism. Glu is involved in diverse processes, namely, protein biosynthesis, cofactor production, nitrogen metabolism, stimulates oxidative processes,

(C) 2020 Salyha N. O. This is an open-access article distributed under the terms of the Creative Commons Attribution License, which permits unrestricted use, distribution, and reproduction in any medium, provided the original author and source are credited. 
increases the body's resistance to hypoxia, has a membrane-stabilizing effect, normalizes metabolism [6-8]. Glu and Cys are important precursors for many biologically active molecules, including GSH (L-gamma-glutamyl-L-cysteinyl-glycine), low molecular weight thiol, present in organism. It worth noting that Cys is a limiting amino acid in GSH synthesis [9-11]. GSH is the major sulfohydryl component $[12,13]$. High GSH concentrations are crucial for redox homeostasis, detoxifications and iron metabolism [14, 15].

The current study focuses on the effects of experimental stress on the oxidative stress markers in the myocardial and spleen tissues of rats. Our goal was to compare the antioxidant effects of Glu, Cys and Glu in combination with Cys on the antioxidant system indicators and the content of lipid peroxidation products in rats under the action of experimental stress.

\section{Materials and Methods}

All procedures were conducted according to the European Convention for the Protection of Vertebrate Animals used for Experimental and Other Scientific Purposes (Strasbourg, 1986) and General Ethical Principles of Experiments using Animals (First National Congress of Bioethics, Kyiv, 2001) in accordance with current legislation on animal experimentation in Ukraine.

Studies were conducted on albino Wistar rats (males) weighing 200-220 g. They were housed in cages under standardized laboratory conditions with a 12-h light/12-h dark cycle. All rats were allowed free access to a standard rodent diet and water ad libitum after 1 week of acclimation rats were divided into five experimental groups (Epinephrine (EPI), EPI/Glu, EPI/Glu/Cys, EPI/Cys, Control). Duration of the study period was 24 hours. Animals from EPI, EPI/Glu, EPI/Glu/Cys and EPI/Cys experimental groups intraperitoneally received epinephrine in a dose $1 \mathrm{mg} / \mathrm{kg}$. After that rats from the EPI/Glu and Glu experimental groups intraperitoneally received an aqueous solution of Glu at the dose $750 \mathrm{mg} / \mathrm{kg}$. Dose of Glu and Cys have been chosen based on their most effective antioxidant properties that were found in our previous exploratory research and literary data analysis [16-18, 20]. Rats of the control group were administered by the appropriate amount of saline. At the end of the experimental period, rats were anesthetized and sacrificed. The myocardial and spleen tissues were rapidly excised and stored at $-80^{\circ} \mathrm{C}$ for further analysis.
The content of lipid hydroperoxides $(\mathrm{LOOH})$ in tissues were determined [19]. The content of $\mathrm{LOOH}$ was calculated by the difference between experimental and control values, and expressed in standard units per gram of tissue. The concentration of thiobarbituric acid reactive substances (TBARS), characterizing the rate of lipid peroxidation based on the reaction between malondialdehyde (MDA) and thiobarbituric acid (TBA) were measured [19]. The values are expressed as nmol of TBARS per gram of tissue. GSH content was determined by the level of thionitrophenyl anion formation as described previously [20]. This colour reaction is based on the interaction between SH-groups of GSH and DTNBA. GSH content was expressed in mmol GSH per gram of tissue.

Glutathione-related enzymes glutathione peroxidase (GPx, EC 1.11.1.9), glutathione-S-transferase (GST, EC 2.5.1.18), glutathione reductase (GR, EC 1.6.4.2) and glucose-6-phosphate dehydrogenase (G6PDH, EC 1.1.1.49) were measured as described earlier [20]. The abovementioned enzyme activities were expressed as GPx (mmol GSH/min/mg protein), GR ( $\mu \mathrm{mol} \mathrm{NADPH} / \mathrm{min} / \mathrm{mg}$ protein), GST (mmol GSH/g tissue), G6PDH ( $\mu \mathrm{mol} \mathrm{NADP}^{+} / \mathrm{min}$ mg protein).

Statistical analysis was performed using a $t$-test or two-way analysis of variance (ANOVA) for comparison of groups. In all cases, reliable differences were considered by $P$ value under 5\% $(P<0.05)$

\section{Results and Discussion}

Antioxidant enzymes protect cells against oxidative stress by an interacting network [21]. GSH is an important intracellular defense against reactive oxygen metabolites. Data of GSH content are shown in Fig. 1.

GSH is regarded as the most important nonenzymatic antioxidant in the heart because of the limited antioxidant enzymes activity [22]. It should be noted that GSH level in myocardial is lower compared to others organs. This is partly linked with low activity of $\gamma$-glutamyltranspeptidase (the enzyme catalyzes the degradation of the extracellular glutathione in the $\gamma$-glutamyl cycle) in rats myocardial tissue [23, 24].

Our studies have shown (Fig. 1) that GSH level in stressed animals differed from animals that additional received Glu, Glu/Cys and Cys. Acute epinephrine-induced stress in the EPI experimental group of rats produced a significant decrease 

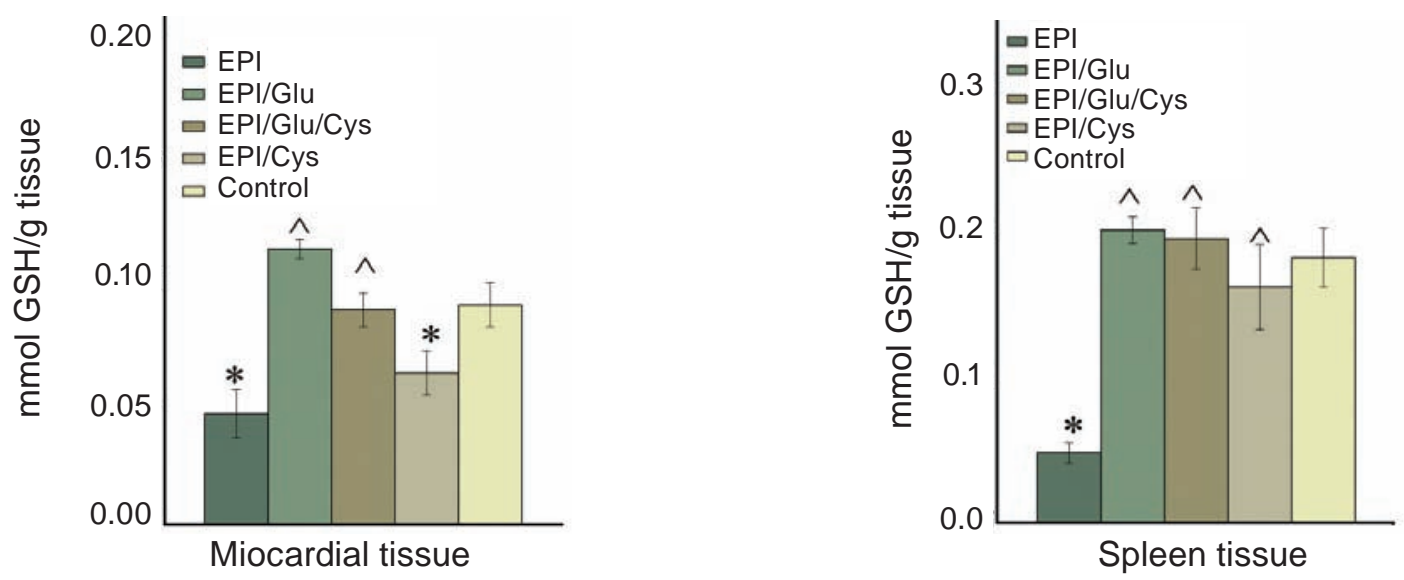

Fig. 1 Effect of Glu, Glu/Cys and Cys on the content of GSH in tissues of rats treated with EPI. Data are means \pm SEM. *Significantly different from the respective control group with $P<0.05$; ^Significantly different from the respective first experimental group with $P<0.05$

$(P<0.05)$ in GSH level in miocardial tissue $(2$ times) and spleen tissue (3.8 times) when compared with control level. The decrease in GSH level found by us may expose the cell to the risk of oxidative damage and may be associated with the intensive use of GSH in metabolic processes. Also has been shown a statistically significant decrease GSH level $(P<0.05)$ in the only stressed group (EPI) compared with animal experimental groups which received amino acids. Namely: in the myocardial of the EPI/ Glu, EPI/Glu/Cys experimental groups by 2.51 and 1.95 times respectively; in the spleen of the EPI/Glu, EPI/Glu/Cys, EPI/Cys experimental groups by 4.23 , 4.10 and 3.40 times respectively. It can be assumed that the level of glutathione was restored with help of the substances we used. It should be noted that the content of GSH in the myocardial tissue of the EPI/Cys experimental group is significantly lower $(P<0.05)$ compared to the control.

GSH is a substrate for GPx which removes $\mathrm{H}_{2} \mathrm{O}_{2}$ and lipid peroxide which is the most dangerous and cytotoxic species in the heart [25]. Data of GPx activity are shown in Fig. 2.

As the results of the research showed, the activity of GPx did not significantly changed in the myocardial tissue of all experimental groups compared to control. In the spleen tissue, on the contrary, revealed significant changes in the activity of GPx. Data show a significant increase in GPx activity (1.4 times) in the spleen of EPI experimental group when compared with the control group $(P<0.05)$. A significant decrease in this index was found in animals of the EPI/Glu, EPI/Glu/Cys, EPI/Cys experimental groups, which after EPI additionally received Glu, Glu/Cys, Cys, respectively, by 1.38; 1.48; 1.59 times compared to control.When comparing this index to animals of the first experimental group (EPI), we found the following authenticity, namely: the activity of GPx was significantly lower in animals of the EPI/Glu experimental group by 1.85 times, in the EPI/Glu/Cys experimental group by 2 times, the EPI/Cys experimental group by 2.12 times.

GR is the enzyme which reduction of GSSG back to GSH. GR is responsible for maintaining the level of GSH in the cells [26, 27].

When analyzing the activity of GR in myocardial and spleen tissues (Fig. 3) in myocardial tissue, the activity of GR was significantly lower in animals of the first experimental group by 4.72 times compared to control. It is also possible to indicate a decrease in this indicator in animals of the EPI/ Cys experimental group by 1.44 times. When comparing the activity of GR with the animals of the EPI experimental group, we found the following authenticity, namely: the activity of GR was increased by 5.65 times in the animals of the EPI/Glu experimental group, the EPI/Glu+Cys experimental group by 4 times, the EPI/Cys experimental group by 3.28 times. The lower activity of GR was also observed in the spleen tissue of all experimental groups as compared to the control animals. Namely, in animals of the EPI experimental group by 2.37 times, in the EPI/Glu experimental group by 1.79 times, animals of the EPI/Glu/Cys experimental group by 1.41 times, animals of the EPI/Cys experimental group by 2.06 times. It will not be superfluous to indicate the 

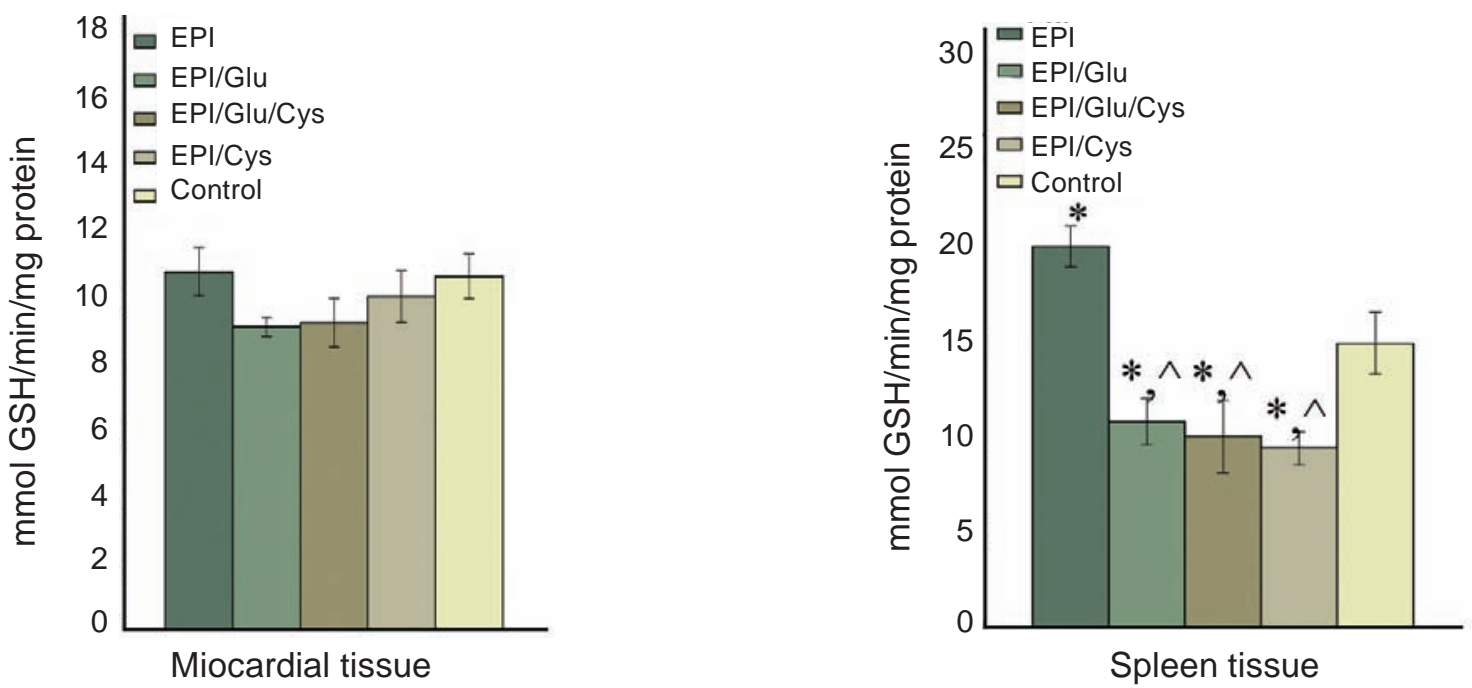

Fig. 2. Effect of Glu, Glu/Cys and Cys on GPx activity in tissues of rats treated with EPI. Data are means $\pm S E M$. *Significantly different from the respective control group with $P<0.05$; ^Significantly different from the respective first experimental group with $P<0.05$
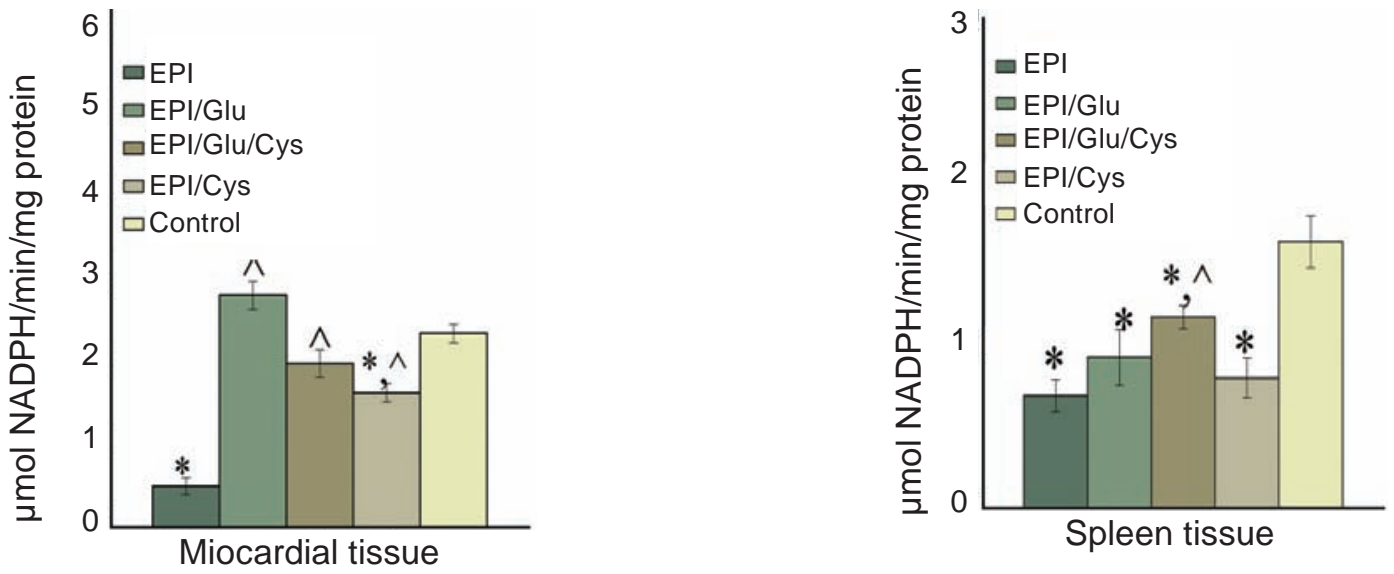

Fig.3. Effect of Glu, Glu/Cys and Cys on GR activity in tissues of rats treated with EPI. Data are means \pm SEM. *Significantly different from the respective control group with $P<0.05$; $\wedge$ Significantly different from the respective first experimental group with $P<0.05$

higher activity of GR in the spleen of animals in the EPI/Glu/Cys experimental group (1.71 times) compared to the animals of the EPI experimental group.

Our research showed (Fig. 4) that the activity of the NADPH-generating enzyme G6PDH in the myocardial and spleen tissues of the EPI experimental group was significantly lower than that of the control group, in particular, in the myocardial tissue (1.86 times), in the spleen tissue (1.66 times). It is worth noting that after the use of epinephrine, the G6PDH activity in the spleen tissue of the fourth experimental group, which additionally received Cys, was significantly lowered. The activity of the investigated enzyme did not show any changes in the above-mentioned tissues of the EPI/Glu and EPI/Glu/ Cys experimental groups, where the indicators almost reached the level of control values. These data may indicate a positive effect of glutamic acid and cysteine, administered both individually and in the complex. As shown in Fig. 4, the activity of G6PDH was significantly higher in animals of the EPI/Glu and EPI/Glu/Cys groups in myocardial tissues, respectively, by 1.82 and 1.61 times, compared to the animals of the EPI experimental group.

The main function of GST is detoxification of a number of compounds by transferring sulfur atoms 

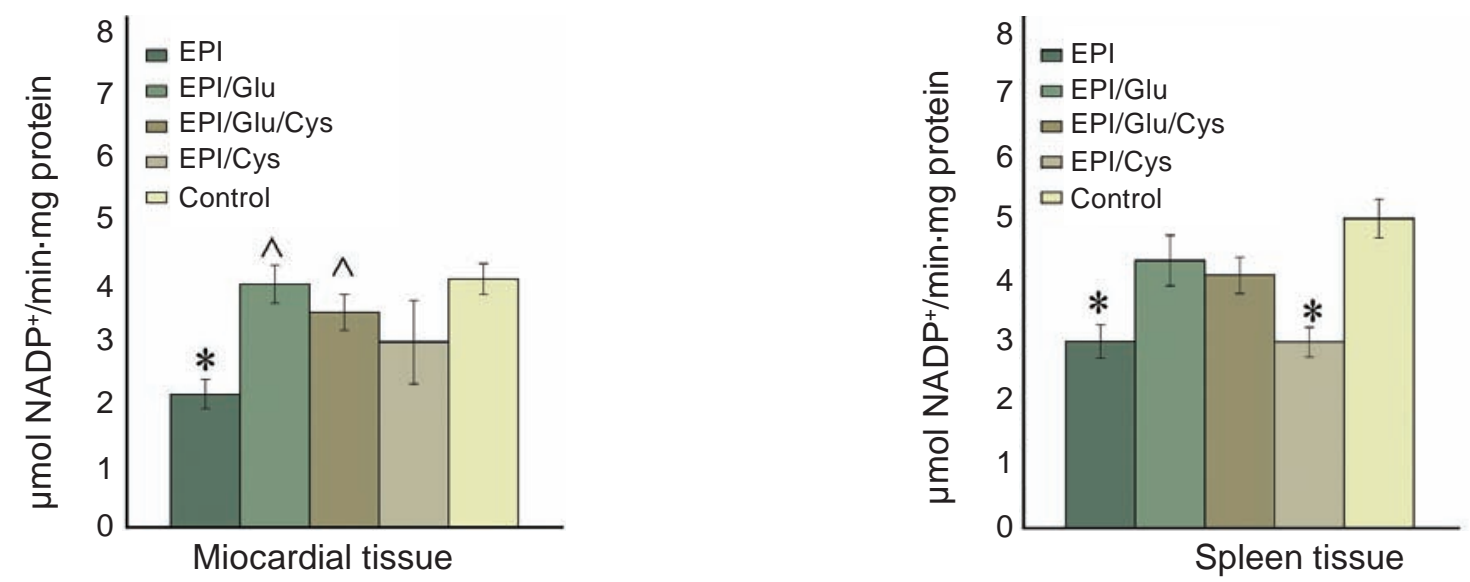

Fig. 4. Effect of Glu, Glu/Cys and Cys on G6PDH activity in tissues of rats treated with EPI. Data are means $\pm S E M$. *Significantly different from the respective control group with $P<0.05$; $\wedge$ Significantly different from the respective first experimental group with $P<0.05$
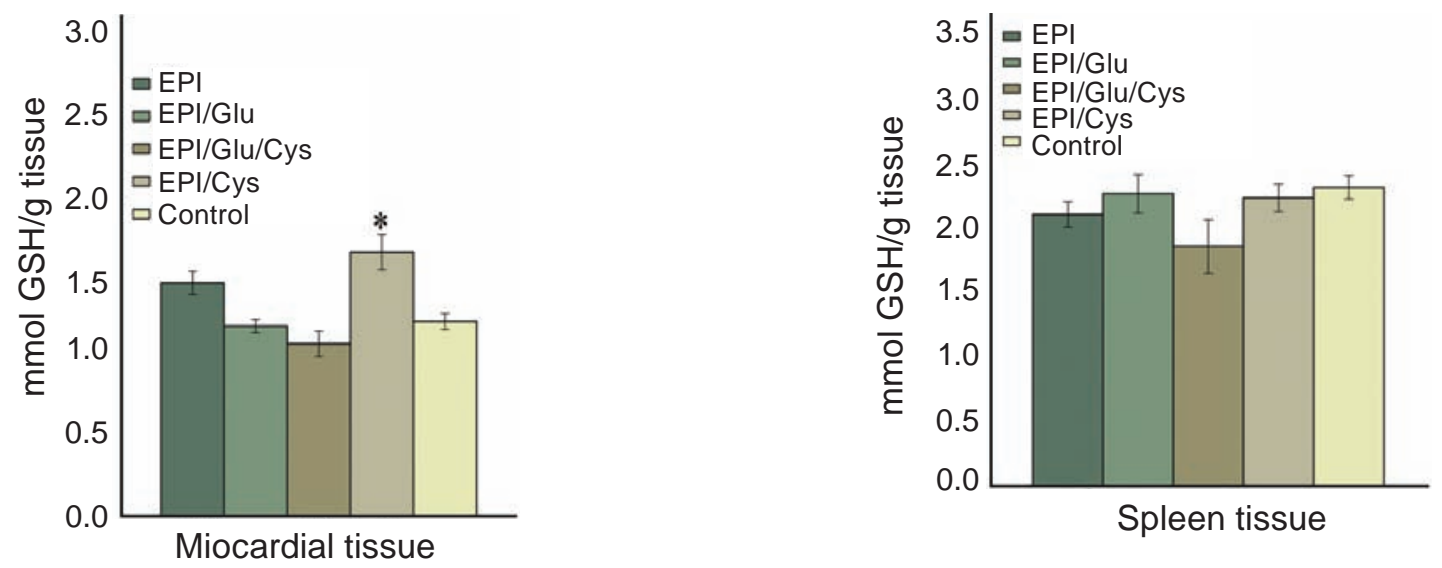

Fig. 5. Effect of Glu, Glu/Cys and Cys on GST activity in tissues of rats treated with EPI. Data are means \pm SEM. *Significantly different from the respective control group with $P<0.05$; $\wedge$ Significantly different from the respective first experimental group with $P<0.05$

to them, followed by the formation of mercaptides. As shown by the results of our studies (Fig. 5), glutathione transferase activity didn't significant changes in any of the experimental groups of the spleen tissue. But it should be noted the increase in this indicator in the myocardial tissue of animals of the fourth experimental group compared with animals of the control group.

The content of lipid hydroperoxides (Fig. 6) in the myocardial tissue of the EPI/L-Glu experimental group of animals was lower by 1.65 times, respectively, compared to the control animals and by 1.62 times as compared to the animals of the EPI experimental group. It should be noted that the $\mathrm{LOOH}$ content in the spleen tissue of the EPI/Glu+Cys experi- mental group was also lower by 1.47 times compared to the control group of animals.

In our studies, intensification of lipid peroxidation under the action epinephrine was found, which was manifested in the increase in the content of TBARS in the myocardial tissue of the first experimental group (1.71 times) compared to the control (Fig. 7). It is worth noting the higher TBARS content in the myocardial tissues of the fourth experimental group (EPI/Cys) by 1.39 times compared to control. Comparing the studied parameter to the animals of the first experimental group, decreasing of TBARS content in the second experimental group of myocardial and spleen tissues was revealed. 

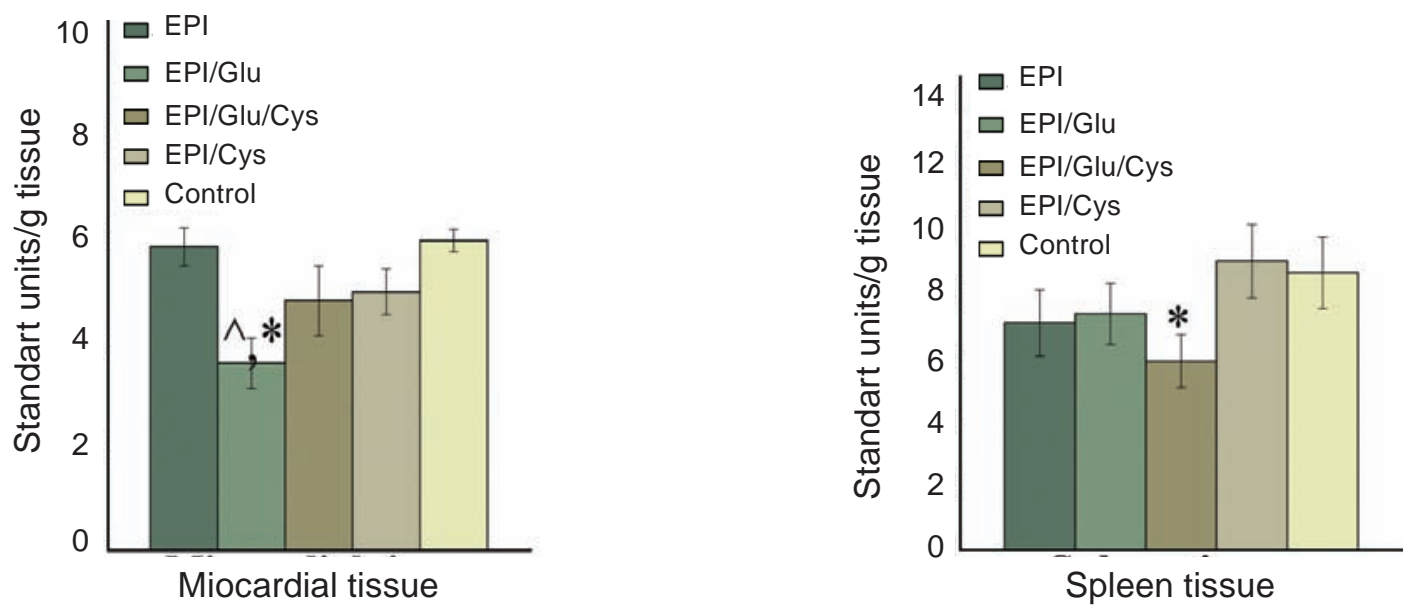

Fig. 6. Effect of Glu, Glu/Cys and Cys on the content of LOOH in tissues of rats treated with EPI. Data are means \pm SEM. *Significantly different from the respective control group with $P<0.05$; $\wedge$ Significantly different from the respective first experimental group with $P<0.05$
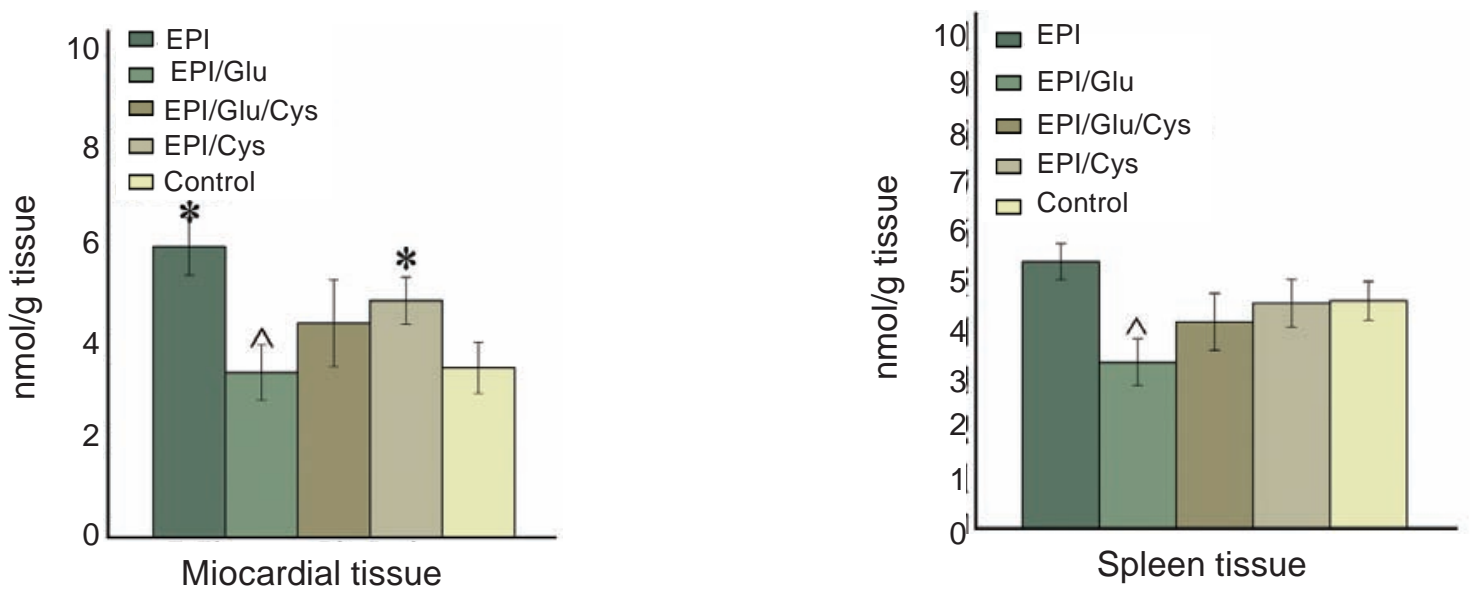

Fig. 7. Effect of Glu, Glu/Cys and Cys on the content of TBARS in tissues of rats treated with EPI. Data are means \pm SEM. *Significantly different from the respective control group with $P<0.05$; $\wedge$ Significantly different from the respective first experimental group with $P<0.05$

Intensification of oxidative stress and decrease of antioxidant status contribute to the development of different deseases. Previous studies have shown that acute stress induced to rats produces an increase in lipid peroxidation products content accompanied by decreased GSH level and activity of antioxidant enzymes [8]. In this study, we tried to investigate relationships between changes of antioxidant system indicators and content of lipid peroxidation products after injection of the Glu, Glu/Cys and Cys and under the action of experimental stress. It should be note, that Glu and Glu/Cys weakened the effect of stress, increasing GSH level to basal levels. When Cys administrated alone, we found less pronounced changes in GSH level. Glu and Cys treated rats alone or in combination showed protective effects on some of the markers evaluated. Our results suggest that acute stress produces noxious effects on the organism and these early changes can be mitigated by agents that have antioxidant properties, such as Glu and Cys. In particular, an important element of the antioxidant system are biomolecules containing sulfhydryl groups. These biomolecules include basic amino acids, one of which is cysteine. It is part of the active centers of enzymes. One of the most important functions of cysteine is to act as a precursor to reduced glutathione, which contains the main pool of sulfhydryl groups and is found in almost all cells. Consequently, further studies are needed to fully characterize the defence mechanism as- 
pects involved in the stress-induced damage in order to further establish base for the development of new therapeutic strategies directed at avoiding the damage produced by oxidative stress.

Conflict of interest. Authors have completed the Unified Conflicts of Interest form at http://ukrbiochemjournal.org/wp-content/uploads/2018/12/coi_ disclosure.pdf and declare no conflict of interest.

Funding. State funding for the research program of the Institute of Animal Biology of NAAS 35.00.02.04 F. No 0116U001413 "Study of biochemical and physiological mechanisms of action of biologically active substances on metabolic processes in animal organism”.

\section{ЕФЕКТИ ГЛУТАМІНОВОЇ КИСЛОТИ ТА ЦИСТЁ̈НУ НА МАРКЕРИ ОКСИДАТИВНОГО СТРЕСУ В ЩУРІВ}

\section{H. О. Салига}

Інститут біології тварин НААН України, Львів; e-mail:ynosyt@yahoo.com

Мета цієї роботи полягала в дослідженні антиоксидантних ефектів глутамінової кислоти (Glu) та цистеїну (Cys) на тлі епінефриніндукованого стресу (ЕРI) в щурів. Тварин було розділено на п'ять груп: ЕРI, EPI/ Glu, EPI/Glu/Cys, EPI/Cys, контрольна. Стрес зумовлювали введенням ЕРІ в дозі 1 мг/кг. Вміст відновленого глутатіону (GSH), активність антиоксидантних ензимів (GPx, GR, GST, G6PD) та вміст продуктів пероксидного окислення ліпідів визначали в тканинах міокарда та селезінки. Встановлено, що за епінефринового стресу в щурів підвищувався вміст продуктів пероксидного окислення ліпідів у міокарді та знижувався рівень GSH у тканинах міокарда та селезінки щурів. Спостерігалося підвищення активності GPx у селезінці лише в стресових тварин, при цьому була значно знижена активність GPx у груп щурів, які додатково отримували амінокислоти (Glu, Glu/Cys, Cys). Одержані результати свідчать про те, що активність GR за дії стресу знижувалась у всіх досліджуваних групах щурів у тканині селезінки та у EPI та EPI/L-Cys груп щурів у тканині міокарда. У групи щурів Glu та Glu/Сys не спостерігали істотної різниці в досліджуваних параметрах. Дійшли висновку, що застосування Glu i Cys окремо або разом частково пом'якшує епінефриніндукований стрес у щурів.

К л ю ч о в і с л о в а: L-глутамінова кислота, L-цистеїн, оксидативний стрес, відновлений глутатіон, антиоксидантні ензими.

\section{References}

1. Espinosa-Diez C, Miguel V, Mennerich D, Kietzmann T, Sánchez-Pérez P, Cadenas S, Lamas S.Antioxidant responses and cellular adjustments to oxidative stress. Redox Biol. 2015; 6: 183-197.

2. Betteridge DJ. What is oxidative stress? Metabolism. 2000; 49(2 Suppl 1): 3-8.

3. Sies H, Berndt C, Jone DP. Oxidative Stress. Annu Rev Biochem. 2017; 86: 715-748.

4. Pisoschi AM, Pop A. The role of antioxidants in the chemistry of oxidative stress: A review. Eur J Med Chem. 2015; 97: 55-74.

5. Farhat Z, Browne RW, Bonner MR, Tian L, Deng F, Swanson M, Mu L. How do glutathione antioxidant enzymes and total antioxidant status respond to air pollution exposure? Environ Int. 2018; 112: 287-293.

6. Walker MC, van der Donk WA. The many roles of glutamate in metabolism. $J$ Ind Microbiol Biotechnol. 2016; 43(2-3): 419-430.

7. Salyha N, Salyha Y. Protective role of l-glutamic acid and l-cysteine in mitigation the chlorpyrifosinduced oxidative stress in rats. Environ Toxicol Pharmacol. 2018; 64: 155-163.

8. Salyha N. Effects of L-glutamic acid and pyridoxine on glutathione depletion and lipid peroxidation generated by epinephrine-induced stress in rats. Ukr Biochem J. 2018; 90(4): 102110.

9. Miller CG, Schmidt EE. Disulfide reductase systems in liver. Br J Pharmacol. 2019; 176(4): 532-543.

10. Stipanuk MH, Ueki I. Dealing with methionine/ homocysteine sulfur: cysteine metabolism to taurine and inorganic sulfur. J Inherit Metab Dis. 2011; 34(1): 17-32.

11. Stipanuk MH, Dominy JE Jr, Lee JI , Coloso RM. Mammalian cysteine metabolism: new insights into regulation of cysteine metabolism. J Nutr. 2006; 136(6 Suppl): 1652S-1659S. 
12. Chiu J, Dawes IW. Redox control of cell proliferation. Trends Cell Biol. 2012; 22(11): 592-601.

13. He L, He T, Farrar S, Ji L, Liu T, Ma X. Antioxidants maintain cellular redox homeostasis by elimination of reactive oxygen species. Cell Physiol Biochem. 2017; 44(2): 532553.

14. Diaz-Vivancos $P$, de Simone A, Kiddle G, Foyer CH. Glutathione-linking cell proliferation to oxidative stress. Free Radic Biol Med. 2015; 89: 1154-1164.

15. Lu SC. Glutathione synthesis. Biochim Biophys Acta. 2013; 1830(5): 3143-3153.

16. Garlick PJ. Assessment of the safety of glutamine and other amino acids. J Nutr. 2001; 131(9 Suppl): 2556S-2561S.

17. Leikin JB, McFee RB, Kerscher R. Handbook of Nuclear, Biological, and Chemical Agent Exposures. CRC Press, 2007: 752 p.

18. Albarracin SL, Baldeon ME, Sangronis E, Petruschina AC, Reyes FGR. L-glutamate: a key amino acid for senory and metabolic functions. Arch Latinoam Nutr. 2016; 66(2): 101-112.

19. Rosalovsky VP, Grabovska SV, Salyha YuT. Changes in glutathione system and lipid peroxidation in rat blood during the first hour after chlorpyrifos exposure. Ukr Biochem $\mathrm{J}$. 2015; 87(5): 124-132.

20. Salyha NO. Activity of the glutathione system of antioxidant defense in rats under the action of L-glutamic acid. Ukr Biokhim Zhurn. 2013; 85(4): 40-47. (In Ukrainian).

21. Lobo V, Patil A, Phatak A, Chandra N. Free radicals, antioxidants and functional foods: Impact on human health. Pharmacogn Rev. 2010; 4(8): 118-126.

22. Couto N, Wood J, Barber J. The role of glutathione reductase and related enzymes on cellular redox homoeostasis network. Free Radic Biol Med. 2016; 95: 27-42.

23. Leeuwenburgh C, Hollander J, Leichtweis S, Griffiths M, Gore M, Ji LL. Adaptations of glutathione antioxidant system to endurance training are tissue and muscle fiber specific. Am J Physiol. 1997; 272(1 Pt 2): R363-R369.

24. SarkarB, Kulharia M, Mantha AK. Understanding human thiol dioxygenase enzymes: structure to function, and biology to pathology. Int $J \operatorname{Exp}$ Pathol. 2017; 98(2): 52-66.

25. Handbook of Oxidants and Antioxidants in Exercise. 1st Edition. Editors: C. Sen, L. Packer, O. Hänninen. 2000. 1220 p.

26. Miller CG, Holmgren A, Arnér ESJ, Schmidt EE. NADPH-dependent and -independent disulfide reductase systems. Free Radic Biol Med. 2018; 127: 248-261.

27. Couto N, Wood J, Barber J. The role of glutathione reductase and related enzymes on cellular redox homoeostasis network. Free Radic Biol Med. 2016; 95: 27-42. 